\title{
Breakthrough of Oscillatoria limnetica and microcystin toxins into drinking water treatment plants - examples from the Nile River, Egypt
}

\author{
Zakaria A Mohamed ${ }^{1 *}$ \\ 'Department of Botany and Microbiology, Faculty of Science, Sohag University, Sohag 82524, Egypt
}

\begin{abstract}
The presence of cyanobacteria and their toxins (cyanotoxins) in processed drinking water may pose a health risk to humans and animals. The efficiency of conventional drinking water treatment processes (coagulation, flocculation, rapid sand filtration and disinfection) in removing cyanobacteria and cyanotoxins varies across different countries and depends on the composition of cyanobacteria and cyanotoxins prevailing in the water source. Most treatment studies have primarily been on the removal efficiency for unicellular Microcystis spp., with little information about the removal efficiency for filamentous cyanobacteria. This study investigates the efficiency of conventional drinking water treatment processes for the removal of the filamentous cyanobacterium, Oscillatoria limnetica, dominating the source water (Nile River) phytoplankton in seven Egyptian drinking water treatment plants (DWTPs). The study was conducted in May 2013. The filamentous O. limnetica was present at high cell densities (660-1 877 cells $/ \mathrm{mL}$ ) and produced microcystin (MC) cyanotoxin concentrations of up to $877 \mu \mathrm{g} \cdot \mathrm{g}^{-1}$, as determined by enzyme-linked immunosorbent assay (ELISA). Results also showed that conventional treatment methods removed most phytoplankton cells, but were ineffective for complete removal of O. limnetica. Furthermore, coagulation led to cell lysis and subsequent microcystin release. Microcystins were not effectively removed and remained at high concentrations $\left(0.37-3.8 \mu \mathrm{g} \cdot \mathrm{L}^{-1}\right)$ in final treated water, exceeding the WHO limit of $1 \mu \mathrm{g} \cdot \mathrm{L}^{-1}$. This study recommends regular monitoring and proper treatment optimization for removing cyanobacteria and their cyanotoxins in DWTPs using conventional methods.
\end{abstract}

Keywords: cyanobacteria, removal, conventional drinking water treatment

\section{INTRODUCTION}

Frequent occurrence of extensive overgrowth of cyanobacteria in water bodies worldwide has been attributed to human activities (Huber et al., 2012; Mohamed and Al-Shehri 2015). The increasing incidence of harmful blooms of cyanobacteria in drinking water sources is a major environmental and public health concern as many of these cyanobacteria can produce potent toxins called cyanotoxins (Merel et al., 2011). Cyanotoxins have been shown to cause adverse human health effects such as gastroenteritis, skin rashes, liver damage and neurotoxic effects (Chorus and Bartram, 1999).

Microcystins (MCs) are the most common cyanotoxins in freshwater sources worldwide, with more than 100 variants identified thus far (Pantelic et al., 2013). They are produced by some cyanobacteria, such as Microcystis, Planktothrix, Oscillatoria, Nostoc, Anabaena and Gloeotrichia (Hisbergues et al., 2003). MCs are extremely stable and resistant to heat, hydrolysis and oxidation (de la Cruz et al., 2011). Human poisoning episodes have been reported upon consumption of drinking water contaminated with MCs. For instance, the death of 60 patients in a hemodialysis clinic in Brazil (Pouria et al., 1998), and the high incidences of primary liver cancer in China (Ueno et al., 1996) and Serbia (Svircev et al., 2009) have been linked to drinking water containing MCs. Moreover, Lévesque et al. (2014) documented a relationship between gastrointestinal symptoms and consumption of drinking water from a plant in Canada equipped with a full treatment system

\footnotetext{
* To whom all correspondence should be addressed. × 00201141705691; e-mail: mzakaria_99@yahoo.com Received: 26 March 2015; accepted in revised form 25 November 2015
}

but whose source water is highly contaminated with cyanobacteria and MCs. These events highlight the importance of adequate water treatment methods to remove cyanobacteria and their toxins to provide safe drinking water.

However, effective removal of cyanobacteria and MCs by conventional methods differs according to the type and concentrations of chemicals used in the water treatment processes, the concentrations of cyanotoxins entering the treatment process, and the cell density of cyanobacteria (Pantelic et al., 2013). Furthermore, removal efficiency could also depend on the cyanobacterial species prevailing in the intake water of treatment plants (Zamyadi et al., 2013). Most studies on the removal of cyanobacteria at drinking water treatment plants were conducted with Microcystis, being the most common species in temperate and tropical freshwater sources (Mohamed and Carmichael, 2000; Zamyadi et al., 2012). Filamentous cyanobacteria, particularly Oscillatoria spp., can dominate both benthic and planktonic cyanobacterial populations in water sources, and some of its species can produce MCs (Mohamed et al., 2006). Oscillatoria limnetica is dominant in the Nile River phytoplankton (Mohamed et al., 2007), and recently regular field observations revealed heavy growth of this species in the intake area of most drinking water treatment plants constructed on the Nile River (Author's personal observation). To our knowledge, no study has been conducted on the removal of this species by conventional methods in drinking water treatment plants. Therefore, the present study was undertaken to study the removal efficiency for O. limnetica during conventional drinking water treatment processes. Simultaneously, microcystin concentrations were monitored in both raw and treated waters to evaluate the release and removal of these toxins during different treatment processes. 


\section{MATERIALS AND METHODS}

\section{Sample preparation}

Water samples were collected from the intake of 7 drinking water treatment plants (DWTPs) along the Nile River, Egypt, and after each step of treatment processes including coagulation/flocculation/sedimentation $(\mathrm{C} / \mathrm{F} / \mathrm{S})$, rapid sand filtration and final treated water. The DWTPs are located 200-300 $\mathrm{m}$ from the banks of Nile. The intakes of DWTPs are $100-120 \mathrm{~m}$ offshore and located at $8-10 \mathrm{~m}$ depth in the Nile River. The names and locations of DWTPs used in this study have been replaced by numbers in accordance with the national safety information laws. Treatment processes include pre-chlorination (3-5 mg. $\left.\mathrm{L}^{-1}\right)$, coagulation/flocculation with $\mathrm{Al}_{2}\left(\mathrm{SO}_{4}\right)_{3}$, sedimentation $(1.5 \mathrm{~h})$, rapid sand filtration and finally chlorine disinfection $\left(2-3 \mathrm{mg} \cdot \mathrm{L}^{-1}\right)$ with a residual concentration of $0.2-0.3 \mathrm{mg} \cdot \mathrm{L}^{-1}$. Water samples were collected within $2-3 \mathrm{~h}$ of midday when there had been no rain for one month. Water samples (1 L) were collected in dark glass bottles, kept at $4^{\circ} \mathrm{C}$ and transported to the laboratory for analyses immediately after sampling. Subsamples of a known volume $(500 \mathrm{~mL})$ of water sample were preserved in $1 \%$ Lugol's solution for phytoplankton analysis. Other subsamples $(250 \mathrm{~mL})$ were filtered through $0.45 \mu \mathrm{m}$ cellulose filter (Whatman, UK) to analyse both intracellular and extracellular toxins.

\section{Phytoplankton analysis}

Phytoplankton in the fixed samples were identified under a light microscope based on taxonomic publications such as Komárek and Anagnostidis (2005). Algal and cyanobacterial cells in raw water and during treatment processes were counted with a hemacytometer and calculated as number of cells per milliliter (cells $\cdot \mathrm{mL}^{-1}$ ). The removal efficiency of each treatment step was represented as the difference in the cell number between each two consecutive steps divided by the cell number found in the former step.

\section{Microcystin analysis}

Intracellular microcystins (cell-bound) were determined by extracting the filters with associated cells in $90 \%$ methanol with sonication. The extract was left overnight at room temperature, and then centrifuged at $10000 \mathrm{~g}$ for $10 \mathrm{~min}$ at $4^{\circ} \mathrm{C}$. The supernatant was air-dried to evaporate the organic solvent, and the remaining aqueous fraction was kept at $-20^{\circ} \mathrm{C}$ till analysis. Extracellular MCs were determined directly in filtered water. MC concentrations were determined by MicrocystinADDA ELISA kit purchased from Abraxis (Warminster, PA, USA) according to the method of Carmichael and An (1999). Negative (deionized water) and positive controls $\left(0.75 \mu \mathrm{g} \cdot \mathrm{L}^{-1}\right.$ MC-LR) were tested by this assay. Analysis was done in triplicate.

\section{Statistical analysis}

Differences in cyanobacterial density and MC concentrations in source water and at different treatment stages were compared by one way ANOVA $(P<0.05)$ using SPSS 17 software for Windows. Correlations between the variables were calculated using the Spearman correlation test.

\section{RESULTS}

Microscopic examination of the source water (Nile River in Egypt) of the seven DWTPs in May 2013 revealed a dominant cyanobacterium, O. limnetica (660-1 877 cells $\left.\cdot \mathrm{mL}^{-1}\right)$ (Table 1). Other phytoplankton taxa of green algae and diatoms at low levels were also found in the source water of these DWTPs (Table 1). The different treatment processes also revealed differential removal of phytoplankton species. Coagulation/ flocculation/sedimentation (C/F/S) removed all green algal cells and about $92-95 \%$ of diatoms from the raw water, but was ineffective for the removal of all cyanobacterial species. While all cells of Gomphosphaera lacustris and Merismopedia elegans were removed during $\mathrm{C} / \mathrm{F} / \mathrm{S}$, the cells of $O$. limnetica were not completely removed. Furthermore, the removal efficiency for O. limnetica by $\mathrm{C} / \mathrm{F} / \mathrm{S}$ varied significantly $(P<0.05)$ among DWTPs surveyed (5.6-86.4\%). Similarly, rapid sand filtration could not effectively (25-34\%) remove the O. limnetica cells that remained after $\mathrm{C} / \mathrm{F} / \mathrm{S}$. In disinfected final treated water, the cell density of O. limnetica cells was reduced by $25-66.7 \%$.

The results of microcystin analysis by ELISA showed that intracellular MCs (cell-bound MCs) in the raw water varied significantly among DWTPs $(P<0.05)$. The highest concentration was detected in the raw water of DWTP $7\left(14.1 \mu \mathrm{g} \cdot \mathrm{L}^{-1}\right)$, while the lowest concentration was in DWTP $4\left(0.66 \mu \mathrm{g} \cdot \mathrm{L}^{-1}\right)$.

\begin{tabular}{|l|c|}
\hline \multicolumn{2}{|c|}{$\begin{array}{c}\text { TABLE 1 } \\
\text { Cell density (cells } \cdot \mathbf{m L}^{-1} \text { ) of phytoplankton present in the } \\
\text { source water of drinking water treatment plants during the } \\
\text { study period }\end{array}$} \\
\hline Species & Cell density \\
\hline Gomphosphaera lacustris. & $86-980$ \\
\hline Merismopedia elegans & $160-1470$ \\
\hline Oscillatoria limnetica & $66-1877$ \\
\hline Cyclotella sp & $20-650$ \\
\hline Nitzschia sp & $60-1020$ \\
\hline Synedra sp. & $30-310$ \\
\hline Pediastrum sp. & $40-160$ \\
\hline Scendesmus sp. & $30-230$ \\
\hline Chlorella sp. & $50-410$ \\
\hline Ankistrodesmus sp & $20-330$ \\
\hline
\end{tabular}

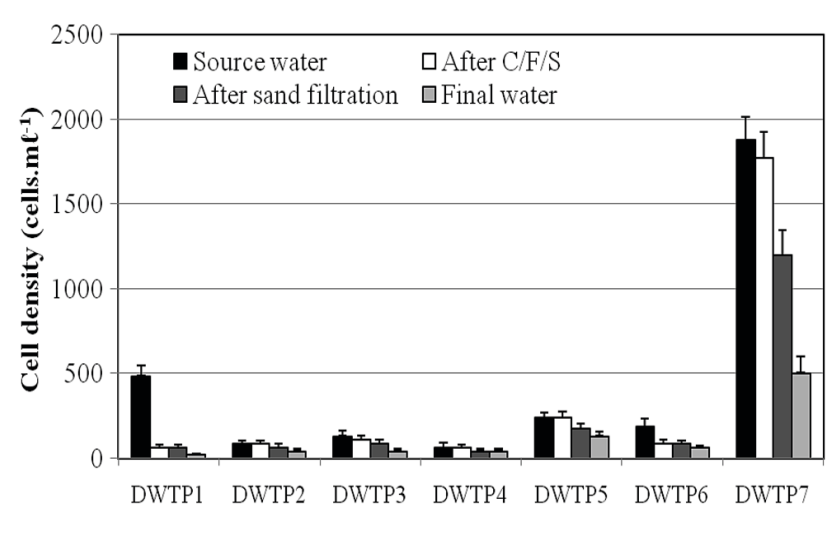

Figure 1

Cell density of Oscillatoria limnetica (cells. $m L^{-1}$ ) in source and treated waters at different water treatment plants in Egypt 
These concentrations of cell-bound MCs associated markedly with the cell density of $O$. limnetica rather than that of other cyanobacterial species present in the samples, indicating that these toxins were mainly produced by this species. In this context, dried material of $O$. limnetica cells isolated from the raw water of DWTP 7 during the present study was analysed and found to contain $877 \mu \mathrm{g} \mathrm{MCs} \cdot \mathrm{g}^{-1}$ dry weight $\left(7.5 \mathrm{pg} \cdot \mathrm{cell}^{-1}\right)$. On the other hand, the concentrations of intracellular MCs decreased sharply along the different treatment stages, reaching its lowest values in the final water of all DWTPs (Fig. 2). Conversely, extracellular MCs (dissolved MCs) were detected at lower concentrations $\left(0.05-0.8 \mu \mathrm{g} \cdot \mathrm{L}^{-1}\right)$ in the source water of all DWTPs (Table 2). But, these concentrations increased dramatically in the clarified water after $\mathrm{C} / \mathrm{F} / \mathrm{S}$ process $\left(0.3-4.2 \mu \mathrm{g} \cdot \mathrm{L}^{-1}\right)$ and sand filtration (0.41-4.4 $\left.\mu \mathrm{g} \cdot \mathrm{L}^{-1}\right)$, and remained without significant change in the final water $\left(0.37-3.8 \mu \mathrm{g} \cdot \mathrm{L}^{-1}\right)$ after chlorine disinfection.

\section{DISCUSSION}

This study reports the presence of the filamentous cyanobacterium, O. limnetica, as the dominant species in the source water (Nile River) of 7 Egyptian DWTPs, with cell densities not exceeding the WHO alert level $1\left(2000\right.$ cells $\left.\cdot \mathrm{mL}^{-1}\right)$ proposed for drinking water monitoring programmes (Chorus and Bartram, 1999). However, this species was found to produce MCs, and its presence in drinking water sources may therefore pose a risk to human health. The O. limnetica strain isolated from groundwater wells in Saudi Arabia (Mohamed and Al-Shehri 2009) has previously been reported to produce microcystins. Cyanotoxins can enter a DWTP in two forms, either as intracellular toxins (inside cyanobacterial cells) or as extracellular (outside the cells) toxins. These toxins should be removed through different treatment processes adopted in DWTPs. In this study, although conventional methods used in DWTPs removed all the cells of green algae and most cyanobacterial species, they were ineffective for the complete removal of O. limnetica cells. The results of this study are thus in accordance with the study of Kommineni et al. (2009) conducted in 8 DWTPs in the USA, which showed selective removal of cyanobacterial species, where Oscillatoria sp., Pseudanabaena sp., and Lyngbya sp. were the least effectively removed species. Similarly, Ewerts et al. (2013) reported the removal of all cyanobacteria except Oscillatoria sp. during coagulation, flocculation and sand filtration. Zamyadi et al. (2013) provided evidence that the efficiency of conventional treatment methods in removing cyanobacterial cells differs among genera. While Anabaena and Microcystis were removed effectively, Aphanizomenon cells were not effectively coagulated and not fully retained on the filter, and passed into chlorinated water at high cell densities (Zamyadi et al., 2013). The discrepancy in the removal efficiency for different genera of cyanobacteria by conventional methods used in DWTPs may be due to specific characteristics, including cell morphology, surface charge and cell density (Henderson et al., 2008). These characteristics influence the mechanism of destabilization of cyanobacterial cells during flocculation (Ewerts et al., 2013). Bernhardt and Clasen (1991) reported that the coagulation of smooth and more or less spherical algal cells occurs largely by charge neutralization, while filamentous algae could be dealt with by sweep coagulation, which requires higher coagulant dosage for precipitation of the metal salts and entrapment of filamentous cyanobacteria and algae on the sweep flocs. Conversely, high doses of coagulant can affect the coagulant charge neutralization mechanism. Exceeding the

\begin{tabular}{|l|c|c|c|c|}
\hline \multicolumn{5}{|c|}{$\begin{array}{c}\text { Table } 2 \\
\text { Concentrations of extracellular microcystins }\left(\boldsymbol{\mu g} \cdot \mathrm{L}^{-1}\right) \\
\text { source and treated waters at different water treatment } \\
\text { plants in Egypt }\end{array}$} \\
\hline \multirow{2}{*}{$\begin{array}{l}\text { Treatment } \\
\text { plants }\end{array}$} & $\begin{array}{c}\text { Microcystin concentrations }\left(\boldsymbol{\mu g} \cdot \mathbf{L}^{-1}\right) \\
\text { Source } \\
\text { water }\end{array}$ & After C/F/S & $\begin{array}{c}\text { After sand } \\
\text { filtration }\end{array}$ & Final water \\
\hline DWTP1 & $0.1 \pm 0.02$ & $0.3 \pm 0.07$ & $0.5 \pm 0.08$ & $0.38 \pm 0.04$ \\
\hline DWTP2 & $0.07 \pm 0.003$ & $0.45 \pm 0.1$ & $0.6 \pm 0.07$ & $0.53 \pm 0.05$ \\
\hline DWTP3 & $0.06 \pm 0.005$ & $0.35 \pm 0.08$ & $0.41 \pm 0.05$ & $0.37 \pm 0.04$ \\
\hline DWTP4 & $0.05 \pm 0.003$ & $0.51 \pm 0.07$ & $0.53 \pm 0.09$ & $0.42 \pm 0.06$ \\
\hline DWTP5 & $0.6 \pm 0.1$ & $1.5 \pm 0.2$ & $1.4 \pm 0.2$ & $1.2 \pm 0.2$ \\
\hline DWTP6 & $0.2 \pm 0.05$ & $0.36 \pm 0.07$ & $0.43 \pm 0.07$ & $0.4 \pm 0.07$ \\
\hline DWTP7 & $0.8 \pm 0.09$ & $4.2 \pm 0.8$ & $4.4 \pm 0.8$ & $3.79 \pm 0.6$ \\
\hline
\end{tabular}

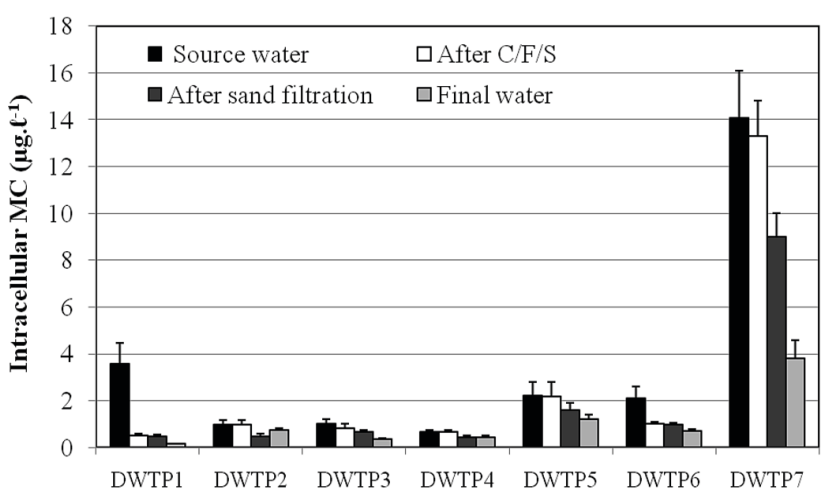

Figure 2

Concentrations of intracellular microcystins $(\mu \mathrm{g} \cdot \mathrm{L}-1)$ in source and treated waters at different water treatment plants in Egypt

water coagulant demand can result in an over-abundance of coagulant positive charges relative to negative charges, thereby destabilizing the particle (Liu and Chin, 2009).

The coagulation process in DWTPs should be adjusted/ optimized according to the type and morphology of algal and cyanobacterial species found in the source water. Furthermore,coagulation/flocculation is not only ineffective for cell removal but also can induce cell lysis and toxin release (Pietsch et al., 2002; Zamyadi et al., 2012). This was also observed in the Egyptian DWTPs, where the extracellular MCs concentrations increased greatly after flocculation in most DWTPs studied, compared to their concentrations in the source water. Additionally, the cell lysis and MC release in the Egyptian DWTPs during coagulation/flocculation process may be due to chlorine pre-oxidation used in these treatment plants, as demonstrated by many authors (Pietsch et al., 2002). On the other hand, the high concentrations of extracellular MCs during $\mathrm{C} / \mathrm{F} / \mathrm{S}$ process may be due to the release of these toxins from cells contained in the sludge as they can break down rapidly (Mohamed et al., 2015). Rapid sand filtration did not effectively remove either O.limnetica cells or MCs, but slightly increased dissolved MC concentrations at all DWTPs studied. Our results are thus in agreement with previous studies reporting that rapid sand filtration is ineffective for the removal of cyanobacterial cells or extracellular cyanotoxins (Ho et al., 2006; Mohamed et al., 2015). Rapid sand filtration can lead to increased dissolved MCs in water due to cell lysis caused by shear stress, inadequate backwashing or cell ageing (Pietsch et 
al., 2002; Zamyadi et al., 2012). MCs may then concentrate in the filter backwash water. Therefore, the filter backwash water should not be returned to the head of the plants for re-use without treatment. Furthermore, chlorine, used as a disinfectant in the final treatment step in Egyptian DWTPs, was ineffective for complete cell removal of O. limnetica (25-67\%) and did not fully degrade MCs. Consequently, MC concentrations in the final treated water in DWTPs 5 and 7 were high (1.3 and $3.8 \mu \mathrm{g} \cdot \mathrm{L}^{-1}$, respectively) and exceeded the WHO provisional guideline limit $\left(1 \mu \mathrm{g} \cdot \mathrm{L}^{-1} \mathrm{MC}-\mathrm{LR}\right)$ for these toxins in drinking water (WHO, 1998). These results are in agreement with previous studies reporting the inefficiency of chlorination in destroying MCs (Zamyadi et al., 2012). The efficiency of MC degradation by chlorination depends on a number of parameters including the type of chlorine compound, the concentration used, $\mathrm{pH}$ and contact time (De la Cruz et al., 2011). For instance, a chlorine dose of $2.8 \mathrm{mg} \cdot \mathrm{L}^{-1}$ for a contact time of 30 min was sufficient to cause $99 \%$ destruction of MC-LR (Tsuji et al., 1997). On the other hand, the inability of chlorination to remove O. limnetica cells may be explained by the fact that the susceptibility of cyanobacterial cells to oxidants is influenced by the species present, the physiological state of the cells, and oxidation conditions (Pietsch et al., 2002; Zamyadi et al., 2012).

In conclusion, this study showed that conventional water treatment processes, such as pre-oxidation, coagulation, sedimentation, sand filtration, and chlorination, in Egyptian DWTPs were ineffective in the elimination of all cyanobacterial cells and/or extracellular MC toxins. These toxins were found in final treated water in two Egyptian DWTPs at concentrations exceeding the $\mathrm{WHO}$ guideline limit proposed for these toxins in drinking water $\left(1 \mu \mathrm{g} \cdot \mathrm{L}^{-1} \mathrm{MC}-\mathrm{LR}\right)$. The efficiency of cell removal can be influenced by the cyanobacterial species, and O. limnetica was the least effectively removed species in these treatment systems. The presence of toxic O. limnetica and/or its MC toxins in the final drinking water poses a risk to human and animal health. Therefore, DWTPs using such conventional treatment methods in Egypt and other countries necessitates alternative treatment approaches to remove cyanobacterial cells and their toxins. The pre-oxidation step which causes cell lysis and toxin release must be eliminated during harmful bloom events of cyanobacteria. The application of activated carbon simultaneously with clarification or in percolation units-has been shown to be efficient in removing extracellular cyanotoxins (Merel et al., 2013). Finally, regular monitoring of cyanobacteria and their cyanotoxins in the source and clarified waters of such DWTPs is necessary for proper treatment optimization.

\section{REFERENCES}

BERNHARDT H and CLASEN J (1991) Flocculation of microorganisms. J. Water Supply Res. Technol. AQUA 40 76-87.

CARMICHAEL WW and AN J (1999) Using of enzyme linked immunosorbent assay (ELISA) and a protein phosphatase inhibition assay (PPIA) for the detection of MCYST and Nodularin. J. Nat. Toxins 7 377-385. http://dx.doi. org/10.1002/1522-7189(199911/12)7:6<377::AID-NT80>3.0.CO;2-8

CHORUS I and BARTRAM J (1999) Toxic Cyanobacteria in Water: A Guide to Their Public Health Consequences, Monitoring and Management. World Health Organization. E. and F.N. Spon, Routledge, London. 416 pp. http://dx.doi. org $/ 10.4324 / 9780203478073$

DE LA CRUZ AA, ANTONIOU MG, PELAEZ M, HISKIA A, SONG W, O'SHEA KE, HE X and DIONYSIOU DD (2011) Can we effectively degrade microcystins? --implications on human health. Anticancer Agents Med. Chem. 11 19-37. http://dx.doi. org/10.2174/187152011794941217
EWERTS H, SWANEPOEL A and DU PREEZ HH (2013) Efficacy of conventional drinking water treatment processes in removing problem-causing phytoplankton and associated organic compounds. Water SA 39 739-949. http://dx.doi.org/10.4314/wsa. v39i5.19

HENDERSON R, PARSONS SA and JEFFERSON B (2008) The impact of algal properties and pre-oxidation on solid-liquid separation of algae. Water Res. 42 1827-1845. http://dx.doi.org/10.1016/j. watres.2007.11.039

HISBERGUES M, CHRISTIANSEN G, ROUHIAINEN L, SIVONEN $\mathrm{K}$ and BORNER T (2003) PCR-based identification of microcystin-producing genotypes of different cyanobacterial genera. Arch. Microbiol. 180 402-410. http://dx.doi.org/10.1007/ s00203-003-0605-9

HO L, MEYN T, KEEGAN A, HOEFEL D, BROOKES J, SAINT CP and NEWCOMBE G (2006) Bacterial degradation of microcystin toxins within a biologically active sand filter. Water Res. 40 768-774. http://dx.doi.org/10.1016/j.watres.2005.12.009

HUBER V, WAGNER C, GERTEN D and ADRIAN R (2012) To bloom or not to bloom: Contrasting responses of cyanobacteria to recent heat waves explained by critical thresholds of abiotic drivers. Oecologia 169 245-256. http://dx.doi.org/10.1007/ s00442-011-2186-7

KOMÁREK J and ANAGNOSTIDIS K. (2005): Cyanoprokaryota 2. Teil/ 2nd Part: Oscillatoriales. - In: Büdel B, Krienitz L, Gärtner G and Schagerl M (eds) Süsswasserflora von Mitteleuropa 19/2. Elsevier/Spektrum, Heidelberg. 759 pp.

KOMMINENI S, AMANTE, K, KARNIK B, SOMMERFELD M and DEMPSTER T (2009) Strategies for controlling and mitigating algal growth within water treatment plants. Water Research Foundation, Denver, Colorado, USA.

LÉVESQUE B, GERVAIS M-C, CHEVALIER P, GAUVIN D, ANASSOUR-LAOUAN-SIDI E, GINGRAS S, FORTIN N, BRISSON G, GREER C and BIRD D (2014) Prospective study of acute health effects in relation to exposure to cyanobacteria. Sci. Total Environ. 466-467 397-403. http://dx.doi.org/10.1016/j. scitotenv.2013.07.045

LIU T-K and CHIN CJM (2009) Improved coagulation performance using performed polymeric iron chloride (PICI). Colloids Surf. A: Physicochem. Eng. Asp. 339 192-198. http://dx.doi.org/10.1016/j. colsurfa.2009.02.029

MEREL S, WALKER D, CHICANA R, SNYDER S, BAURÈS E and THOMAS O. (2013) State of knowledge and concerns on cyanobacterial blooms and cyanotoxins. Environ. Int. 59 303-327. http:// dx.doi.org/10.1016/j.envint.2013.06.013

MOHAMED ZA and AL-SHEHRI AM (2009) Microcystins in groundwater wells and their accumulation in vegetable plants irrigated with contaminated waters in Saudi Arabia. J. Hazardous Mater. 172 310-315. http://dx.doi.org/10.1016/j.jhazmat.2009.07.010

MOHAMED ZA and CARMICHAEL WW (2000) Seasonal variation in microcystin levels of River Nile water at Sohag City, Egypt. Ann. Limnol. 36 227-234. http://dx.doi.org/10.1051/limn/2000020

MOHAMED ZA, EL-SHAROUNY HM and ALI WSM (2007) Microcystin concentrations in the Nile River sediments, and removal of microcystin-LR by sediments during batch experiments. Arch. Environ. Contam. Toxicol. 52 489-495. http://dx.doi. org/10.1007/s00244-006-0140-1

MOHAMED ZA, DEYAB MA, ABOU-DOBARA MI, EL-SAYED AKA and EL-RAGHI WM (2015) Occurrence of cyanobacteria and microcystin toxins in raw and treated waters of the Nile River, Egypt: Implication for water treatment and human health. Environ. Sci. Pollut. Res. 22 11716-11727. http://dx.doi.org/10.1007/ s11356-015-4420-z

MOHAMED ZA and Al-SHEHRI AM (2015) Biodiversity and toxin production of cyanobacteria in mangrove swamps in the Red Sea off the southern coast of Saudi Arabia. Botanica Marina 58 23-34. http://dx.doi.org/10.1515/bot-2014-0055

MOHAMED ZA, EL-SHAROUNY HM, ALI WSM (2006) Microcystin production in benthic mats of cyanobacteria in the Nile River and irrigation canals, Egypt. Toxicon 47 584-590. http://dx.doi. org/10.1016/j.toxicon.2006.01.029

PANTELIC D, SVIRCEV Z, SIMEUNOVIC J, VIDOVIC M and 
TRAJKOVIC I (2013) Cyanotoxins: Characteristics, production and degradation routes in drinking water treatment with reference to the situation in Serbia. Chemosphere 91 421-441. http://dx.doi. org/10.1016/j.chemosphere.2013.01.003

PIETSCH J, BORNMANN K and SCHMIDT W (2002) Relevance of intra and extracellular cyanotoxins for drinking water treatment. Acta Hydrochim. Hydrobiol. 30 7-15. http://dx.doi. org/10.1002/1521-401X(200207)30:1<7::AID-AHEH7>3.0.CO;2-W

POURIA S, ANDRADE DE A., BARBOSA J, CAVALCANTI RL, BARRETO VTS., PREISER W, POON GK, NEILD GH and CODD GA (1998) Fatal microcystin intoxication in haemodialysis unit in Caruaru, Brazil. Lancet 352 21-26. http://dx.doi.org/10.1016/ S0140-6736(97)12285-1

SVIRCEV Z, KRSTIC S, MILADINOV-MIKO M, BALTIC V and VIDOVIC M (2009) Freshwater cyanobacterial blooms and primary liver cancer epidemiological studies in Serbia. J. Environ. Sci. Health C 1532-4095 36-55. http://dx.doi. org/10.1080/10590500802668016

TSUJI K, WATANUKI T, KONDO F, WATANABE MF, NAKAZAWA H, SUZUKI M, UCHIDA H and HARADA KI (1997) Stability of microcystins from cyanobacteria - IV. Effect of chlorination on decomposition. Toxicon 35 1033-1041. http://dx.doi.org/10.1016/ S0041-0101(96)00223-1

UENO Y, NAGATA S, TSUTSUMI T, HASEGAWA A,WATANABE MF, PARK H-D, CHEN GC and YU S-Z (1996) Detection of microcystins, a blue-green algal hepatotoxin, in drinking water sampled in Haimen and Fusui, endemic areas of primary liver cancer in China, by highly sensitive immunoassay. Carcinogenesis 17 13171321. http://dx.doi.org/10.1093/carcin/17.6.1317

WORLD HEALTH ORGANIZATION (WHO) (1998) Guidelines for Drinking Water Quality. Addendum to Volume 1. Recommendations ( $2^{\text {nd }}$ edn). World Health Organization, Geneva. $36 \mathrm{pp}$.

ZAMYADI A, FAN Y, DALY RI and PREVOST M (2013) Chlorination of Microcystis aeruginosa :toxin release and oxidation, cellular chlorine demand and disinfection by-products formation. Water Res. 47 1080-1090. http://dx.doi.org/10.1016/j.watres.2012.11.031

ZAMYADI A, MACLEOD S, FAN Y, MCQUAID N, DORNER S, SAUVE S and PREVOST M (2012) Toxic cyanobacterial breakthrough and accumulation in a drinking water plant: a monitoring and treatment challenge. Water Res. 46 1511-1523. http://dx.doi. $\operatorname{org} / 10.1016 /$ j.watres.2011.11.012 